Vol. 4, $n^{\circ} 1 \mid 2000$

Varia

\title{
"It's a Mystery » : the Royal Prerogative of Mercy in England, Canada and South Africa
}

Rob Turrell

\section{(2) OpenEdition}

Electronic version

URL: https://journals.openedition.org/chs/850

DOI: $10.4000 /$ chs. 850

ISSN: 1663-4837

Publisher

Librairie Droz

Printed version

Date of publication: 1 January 2000

Number of pages: 83-101

ISBN: 2-600-00433-5

ISSN: $1422-0857$

\section{Electronic reference}

Rob Turrell, "«It's a Mystery » : the Royal Prerogative of Mercy in England, Canada and South Africa", Crime, Histoire \& Sociétés / Crime, History \& Societies [Online], Vol. 4, $n^{\circ} 1 \mid 2000$, Online since 02 April 2009, connection on 22 March 2022. URL: http://journals.openedition.org/chs/850 ; DOI: https:// doi.org/10.4000/chs.850 


\title{
«lt's a Mystery»: the Royal Prerogative of Mercy in England, Canada and South Africa
}

\author{
Rob Turrell'
}

This essay asks the question: on what grounds were murderers reprieved in England, Canada and South Africa in the nineteenth and twentieth centuries? It weighs up three interpretations. Radzinowicz and Hood argue that mercy decisions were made on the basis of the law. Murders committed with the two elements of deliberation and planning were punished by death. Roger Chadwick argues that execution depended on the social and moral meaning of a murder and not the legal definition of an intent to kill. And, third, Carolyn Strange argues that mercy in Canada was awarded arbitrarily. Hanging was a form of lottery. A detailed examination of judicial and administrative mercy reports in South Africa reveals that decisions were made on the basis of a legal definition of intent, but that the finding of intent was always determined by the social and moral meaning of a murder. To illustrate this point three similar domestic and intra-racial South African murders are examined in detail.

Cet article porte sur les motivations de la grâce des meurtriers en Angleterre, au Canada et en Afrique du Sud aux XIX $X^{e}$ et XX $X^{e}$ siècles. Il évalue trois interprétations: Radzinowicz et Hood affirment que les décisions de grâce se fondaient sur des motifs juridiques. Les homicides qui étaient à la fois délibérés et préparés étaient punis de mort. Roger Chadwick estime que l'exécution dépendait de la signification sociale et morale du meurtre et non de la qualification légale de l'intention homicide. Troisièmement, Carolyn Strange prétend, qu'au Canada, la grâce était accordée arbitrairement. La pendaison était une sorte de loterie. L'examen détaillé des dossiers administratifs et judiciaires de grâce Sud-africains montre que les décisions reposaient sur une définition légale de l'intention, mais que l'analyse de l'intention était toujours déterminée par la signification sociale et morale de l'homicide. Trois meurtres sud-africains, analogues par leur caractère domestique et intra-racial, sont analysés en détail pour étayer cette thèse.

Tn Shakespeare's Merchant of Venice there are those memorable lines that lexpress the meaning of mercy:

Rob Turrell is the author of Capital and Labour on the Kimberley Diamond Fields, 1871-1890 (Cambridge, Cambridge University Press, 1987) and White Mercy. A History of Murder and Rape in South Africa (Cape Town, University of Cape Town Press, 2000). The research for this article was conducted while he was employed as a Deutsche Forschungsgemeinschaft Research Fellow in the Historisches Seminar at the University of Hannover, Germany. He currently works in the Dean's Office, Faculty of Humanities, University of Cape Town. 
The quality of mercy is not strain'd;

It droppeth as the gentle rain from heaven

Upon the place beneath: it is twice blessed;

It blesseth him that gives, and him that takes:

"Tis mightiest in the mightiest; it becomes

The throned monarch better than his crown:

His sceptre shows the force of temporal power,

The attribute to awe and majesty,

Wherein doth sit the dread and fear of kings;

But mercy is above this sceptered sway,

It is enthroned in the hearts of kings,

It is an attribute of God himself.

Mercy had long been an attribute of the monarch and derived from his or her divine right to rule. But mercy was, in Douglas Hay's classic account of eighteenthcentury England, a discretionary instrument whose exercise confirmed the mental structures of paternalism and deference in a justification of the social order. "It allowed the rulers of England to make the courts a selective instrument of class justice, yet simultaneously to proclaim the law's incorruptible impartiality, and absolute determinacy,' explained Hay. (...) It allowed the class that passed one of the bloodiest penal codes in Europe to congratulate itself on its humanity $»^{2}$. At this time a multitude of property offences were capital crimes, but by 1861 capital punishment was effectively restricted to murder alone. In what follows I try to unravel the mystery of mercy in the post-1861 period in England and two of its former colonies, Canada and South Africa.

\section{1. - PREMEDITATION AND ENGLISH MURDER LAW}

If a murderer was convicted in England and Wales between the years of 1861 and 1957, he or she was sentenced to death. There was a mandatory death penalty for murder. The English common law defined murder «as unlawful killing with malice aforethought $»^{3}$. But by 1861 malice had long ceased to mean malice (that is, ill-will), and aforethought had also come adrift from its original meaning (premeditation). How, then, did judges instruct juries on finding an intent to kill or «malice aforethought $»$ ? There were two main (there were more) forms of malice. First, malice (the intent, the mens rea, the guilty mind) was express when the killer had made preparations, used threats or said something immediately before or after the assault that revealed his intention to kill. Second, malice was implied from the place the victim was struck on the body, the weapon used (the use of a firearm implied an intent to kill, but not the use of a light stick) or the number of blows inflicted (one blow might indicate an intent to injure, but twenty stab wounds implied an intent to kill). In the nineteenth and the first quarter of the twentieth century most murderers were hanged on the doctrine that a man intended the natural and probable consequences of his acts. This doctrine of implied malice, of course, made it much easier

Hay $(1977$, p. 48).

Gowers (1956, p. 33). 
for the Crown to win a conviction. It was much more difficult to gather an intent to kill from threats or plans made, especially where most murderers were illiterate.

What this meant was that premeditation was not a requirement for a murder conviction. For example, in 1879 Lord Justice The singer told a jury «that it was not necessary to find premeditation in order to convict of murder, but only that the deed was committed with what is legally called malice, that is to say with a wicked or cruel mind ${ }^{4}$. This was in sharp contrast to the murder law in most American states, where there was a division into capital and non-capital murder on the basis of «premeditation ». Although the law varied in detail from state to state, all states relied on the original model of the 1794 Pennsylvania Statute. First-degree murder included murders «(a) perpetrated by means of poison, or by lying in wait, or by any other kind of wilful, deliberate and premeditated killing» and «(b) committed in the perpetration or attempt to perpetrate any arson, rape, robbery or burglary ${ }^{5}$. Seconddegree murder included all other murders that were murder at common law.

The most extended English attempt to devise a legal way of restricting hanging to the most heinous murders was undertaken in the Royal Commission on Capital Punishment (1949-1953). It had long been recognised that there were many different types of murders and that they were not all equally culpable. «There is probably no offence», wrote Ernest Gowers, the Chairman of the Commission, in the little book he published to popularise the Commission's conclusions, «that varies so widely both in character and in moral guilt as that which falls within the legal definition of murder ${ }^{6}$. When the Commission sat the only way of confining hanging to the worst murders was through the Royal Prerogative of Mercy. The Prerogative was exercised in secret on the King's behalf by the Home Secretary and in the first half of the twentieth-century he reprieved half of those sentenced to death. There were some well-worn objections to this Prerogative, perhaps no better expressed than by Mr Justice Devlin:

... the Prerogative of Mercy is now perforce being used in circumstances for which it was never designed, not for the exercise of mercy but for the determination of justice. The inquiry into the appropriate sentence which, in accordance with all our traditions, ought to be dealt with in open court and with the right of appeal, has to be conducted in camera and without appeal on facts that may or may not have emerged in evidence and been tested in cross-examination... Traditionally, we have insisted that the subject should be protected by forms of law; that is what we mean by saying that no man shall be condemned save by due process of law. The law does not achieve that by telling those to whom it has denied justice that they can always sue for mercy?

What alternatives were there to the mercy prerogative? The most popular alternative the Royal Commission considered was the American option of two degrees of murder. But the Commission decided that premeditation was not a valid ground on which to divide murder. «A sudden killing may be the direct expression of an

4 Quoted in Chadwick (1992, p. 107).

5 Royal Commission on Capital Punishment, 1949-1953, Report, p. 182.

6 Gowers (1956, p. 29).

7 Gowers (1956, p. 32), quoting from an article by Lord Devlin in the Criminal Law Review, September 1954 
incorrigibly vicious nature», the Royal Commission on Capital Punishment 19491953 noted, "while a premeditated and deliberate murder may be among the most excusable ${ }^{8}$. The Royal Commission found, according to Ernest Gowers' summary, that there had been two unfortunate consequences of the two-degree murder law in America. First, there had been some judgements that lacked common sense. «In one State it has been held that an instant of time is enough to admit of premeditation ", wrote Gowers. «That makes nonsense of the distinction; premeditation becomes the same as intent ». Second, juries ignored the law and found an accused guilty of firstdegree murder if they thought he ought to die, and of second degree if they thought there was some mitigating factor. «What we have is merely a privilege offered to the jury to find the lesser degree when the suddenness of the intent, the vehemence of the passion, seems to call irresistibly for the exercise of mercy ", wrote the New York judge, Justice Cardozo, in 1930. «I have no objection to giving them this power, but it should be given to them directly, and not in a mystifying cloud of words $"{ }^{9}$. In the light of this, and much other weighty consideration, the Royal Commission concluded that there was simply no way to classify murder: "the object of our search is chimerical and must be abandoned ${ }^{10}$. And the English murder law remained unaltered until the 1957 Homicide Act made certain categories of murder non-capital and that in turn was a short remove from a moratorium on executions in 1961 and the abolition of capital punishment in 1966.

\section{2. - ENGLAND: MERCY RULES OK}

On what grounds, then, did the Home Secretary reprieve half of those and more murderers sentenced to death under the mandatory death penalty? There are three conflicting historical interpretations of the way mercy was exercised. The first suggests that decisions were made on the basis of the law. Leon Radzinowicz and Roger Hood argue in their History of English Criminal Law (1986), based on published and printed Home Office sources, that the Home Secretary distinguished between two degrees of murder in granting mercy. The distinction was based on a recommendation of the 1866 Royal Commission on Capital Punishment that defined firstdegree murder «as all murders deliberately committed with express malice aforethought, such malice to be found as a fact by the jury...». The essence of deliberation is a calm contemplation of an act and its consequences. Coldblooded was a popular synonym for deliberate. The essence of express malice is evidence of planning in the crime. It is quite possible to have a deliberate murder that is not planned. And it is quite possible to have a planned murder that is not deliberate, but rather the result of a disturbed or unhinged mind. Thus, first-degree murders, containing the two elements of deliberation and planning, were to be punished by death. Second-degree murders were to be punished by a gaol sentence of from seven years to life. The numerous attempts to change the murder law in this direction all failed in the House of Commons. Yet in practice, say Radzinowicz

\footnotetext{
8 Gowers (1956, p. 37).

9 Gowers (1956, p. 38).

10 Gowers (1956, p. 39).
} 
and Hood, the Home Secretary simply used this unacceptable legal distinction in the exercise of mercy ${ }^{11}$.

The second interpretation argues that mercy decisions were made through an assessment of the social and moral meaning of a murder. Roger Chadwick, who examined capital case files in the Home Office during the late Victorian period, argues that Home Secretaries seldom queried the jury's finding of an intent to kill. Instead, they commuted on the basis of other mitigating factors. "Who was killed, how was it done, were all questions whose answers seem to have affected the imputations of malice $»^{12}$. What this meant was that intention, despite its legal definition, was always socially determined in the granting of mercy. Home Secretaries had to determine what was a bad murder. They did not use premeditation, as Chadwick thinks Radzinowicz and Hood suggest, to differentiate murders. They had to assess the social meaning of homicide. "The decisions which they came to in this respect», wrote Chadwick, «are at once the most important indications of the values which they sought to protect and the most elusive $»^{13}$.

This social and moral approach to mercy was what the Home Office itself dubbed as «no fixed rules». In 1874 a Home Office internal memo stated that the Prerogative of Mercy was "governed by no fixed rules or forms of procedure $»^{14}$. But «no fixed rules» did not mean that there were no rules in deciding on mercy. It simply meant that the rules were not fixed. In 1907 Herbert Gladstone, the Home Secretary (1905-1910), gave the best insight into the way mercy was exercised:

It would be neither desirable nor possible to lay down hard and fast rules as to the exercise of the prerogative of mercy. Numerous considerations - the motive, the degree of premeditation or deliberation, the amount of provocation, the state of mind of the prisoner, his physical condition, his character and antecedents, the recommendation or absence of recommendation from the jury, and many others have to be taken into account in every case: and the decision depends on a full review of a complex combination of circumstances and often on the careful balancing of conflicting considerations $(\ldots)^{15}$.

Here, it is important to note that in addition to «no fixed rules » Gladstone mentions the degree of premeditation or deliberation in his bundle of factors to be weighed in mitigation of murder.

Sir Edward Troup, who started in the Criminal Department in 1880 as a clerk and became Permanent Under-Secretary in 1908, was able to reveal in his book on the Home Office published in 1925 that an archive of rule and precedent made it possible to decide on mercy very quickly. Although he was careful to say that «no

11 Radzinowicz, Hood (1986, pp. 677-681).

12 Chadwick (1992, p. 387).

13 Chadwick (1992, p. 386). The idea that mercy was determined by social and moral rather than legal reasons is also argued by Richard Evans in his examination of the death penalty in Germany. There he found that in Victorian Prussia the two most important factors in granting mercy were the type of murder and the motive. Those murders that did not threaten the social hierarchy and were not motivated by greed or revenge were most likely to lead to a reprieve. In fact, Evans makes little reference to either intent or premeditation. This implied that the exercise of mercy was uncoupled from the legal process entirely. There is certainly support for this interpretation in the fact that so few middleclass murderers were executed (Evans, 1996, pp. 285-305).

HO 45.9362/33391, 1874, quoted in Gatrell $(1994$, p. 201).

Parliamentary Debates, H.C., Vol 172, 11 April 1907, 366. 
general principle can be formulated», there were «certain classes of cases in which something approaching to a rule can be laid down ${ }^{16}$. Here is Troup's list of nine rules: first, no one under 18 was executed, while above that age youth was «one of the considerations to which weight is given, but which is not by itself conclusive in the case of a cold blooded and cruel murder "; second, infanticides were reprieved and had been since 1849, but baby farmers were executed; third, constructive malice in murder presented difficulties because arson and rape had led to horrible crimes; fourth, abortion was technically murder, but judges allowed a manslaughter finding; fifth, survivors of suicide pacts were treated mercifully and given short sentences; sixth, «provocation sometimes is, and sometimes is not, a sufficient reason for commutation of the capital sentence" and here cases ranged from clear evidence of an unhinged mind, which was treated mercifully, to clear evidence of revenge, which was not, but most cases lay between these two extremes and were decided on other considerations like age or character; seventh, drink was assessed similarly to provocation; eighth, a jury's mercy recommendation was usually honoured provided there was «some reasonable ground» and the judge agreed; ninth, insane murderers were not hanged but sent to Broadmoor, and borderline insanity cases, «though negatived by the jury or not raised at the trial ", were considered after conviction ${ }^{17}$.

Twenty five years later the Royal Commission on Capital Punishment (19491953) learned from the Home Office that the exercise of mercy was based on a «broad-based body of doctrine» and that decisions gave rise to little difficulty. Reprieves were «foregone» in cases of mercy killings, suicide pacts, infanticide and maternal child murder. There were other types of murder that were considered for reprieve and here the Commission noted insanity, youth, drink and provocation in similar terms to that spelt out by Troup in his book. What was different to Troup was a number of new categories of murder considered suitable for reprieve. Here there was a new concern with premeditation. First, « unpremeditated murders committed in some sudden excess of frenzy, where the murderer has previously had no evil animus towards his victim, especially if he is weak-minded or emotionally unstable to an abnormal degree». Second, «murder committed without intent to kill... in course of a quarrel ». Third, murders committed by two or more people with different degrees of responsibility. Fourth, there was a «natural reluctance» to hang women and, in the words of the Home Office memo to the Commission, «there have been occasions on which the Home Secretary of the day has expressly had regard to the prisoner's sex in deciding to recommend commutation». Fifth, high-profile cases were affected by the force of public opinion. Mercy was occasionally extended « on the ground that it would do more harm than good to carry out the sentence if the result was to arouse sympathy for the offender and hostility to the law $»^{18}$.

\section{3. - CANADA: NO MERCY RULES}

The third interpretation of the exercise of mercy was that there were «no rules». The award of mercy was arbitrary or akin to a game of chance. Hanged men and

16 Troup $(1925$, p. 65).

17 Troup (1925, pp. 55-71).

18 Royal Commission on Capital Punishment, 1949-1953, Report, pp. 10-12. 
women drew short straws in a lottery. This view has been argued by the Canadian historian, Carolyn Strange ${ }^{19}$. Canadian mercy practice was derived from the English Home Office and the mandatory death penalty for murder was maintained in Canada until 1961. Unlike in England where the responsibility for mercy lay with the Home Secretary alone, in Canada the Governor-General was responsible for mercy subject to the advice of his cabinet.

Twentieth-century Canadian capital-case records are open to the public and in a researcher-friendly form. This is in stark contrast to England where the files are closed for a hundred years. The Canadian archives contain trial transcripts, judges' reports, Justice Department evaluations, and cabinet decisions. For some wonderful and unexplained reason the National Archives of Canada has created a dataset of the contents of these files in DBase 4 format. This means that researchers can quantify accused and victims' age, race, occupation, marital status, religion, as well as judges' conviction records, their jurisdictions, the weapons used, and the motives for murders in 1,533 cases between 1867 (Confederation) and 1976 (abolition of capital punishment). Quantification reveals that mercy was awarded in a discriminatory fashion. There appears to be no quarrel with this conclusion. According to Strange the murderers most likely to be executed in Canada between 1926 and 1957 were « offenders with prior criminal records; labourers; Aboriginals, ethnic minorities or French Canadians; murderers of policemen or high-status victims; those whose crimes were particularly brutal, or who committed murder in the course of another felony ». This statistical profile was different to that of the convicted murderer who «was most likely to be a low-status, Anglo male in his early thirties with no dependents ${ }^{20}$. But Strange goes further. «Qualitative evidence adds texture to the statistical outline of discrimination », she writes:

At the micro-level of case studies, we can see that cabinets conducted case reviews like primitive lotteries - as if they drew lots to determine whether or not to execute. The results were not random because condemned people ended up with different combinations of short and long lots representing factors - both legal and extra legal - that cabinets considered. The conviction, of course, was a short straw, so advocates of the condemned scrambled to find longer ones: steady workers, selfsacrificing mothers, or beloved members of communities could be constructed as persons meriting mercy. Alternatively, people with histories of combativeness, as well as outsiders of all sorts, tended to fare poorly. Racist and class-based assumptions were also at play, yet these forms of discrimination did not always operate to the disadvantage of those sentenced to die. Racist notions of intelligence and moral character, for example, could inspire pity for people of «lesser» races. Furthermore, persons subjected to colonisation schemes, particularly Aboriginal peoples during early phases of contact with whites, were often treated leniently by paternalistic cabinets. Some saw their luck shift because their cases arose in the wake of a controversial hanging or commutation; others benefitted or suffered because their reviews occurred when cabinets were bombarded by lobbyists. In other words, patterns of severity were generally disfavourable to the poor, to men, and to those from identifiable racial and ethnic groups, but the drawing of lots on a case-by-case basis yielded surprises. Such was the drama of capital punishment ${ }^{21}$.

19 Strange (1996, pp. 594-561); Strange (ed.) (1996); Strange (1998a, pp. 184-197); Strange (1998b, pp. 25-48).

20 Strange (1998b), summarising material in Avio (1987, pp. 366-379); Avio (1988, pp. 331-349); Chandler, (1976); Jayewardene (1977).

21 Strange (1998b, p. 596). 
It is confusing to call the award of mercy a discriminatory lottery. This is an oxymoron like «irresistible impulse». The word irresistible implies the notion of compulsion, while impulse suggests the exact opposite. Similarly, the discrimination Strange refers to is not random or arbitrary but its exact opposite. Discrimination played an important systematic function in the control of crime. Here, I think, Strange was seduced by the linguistic propinquity in the extraordinary fact that the Canadian parliament chose in 1953 to establish a Special Joint Committee to investigate «capital punishment, corporal punishment and lotteries». She was also influenced by arguments around the struggle for the abolition of capital punishment in the 1950s and 1960s and projected them back into the past. "Although humanitarian sentiment motivated most abolitionists, their arguments against cruelty and unfairness ultimately proved less persuasive than their charges of irrationality and unaccountability in the disposition of capital cases $»^{22}$. Unprincipled and partial justice, she tells us, led to the abolition of the death penalty.

Strange also calls the award of mercy a mystery ${ }^{23}$. Cabinet members refused to explain their decisions, claiming executive privilege. She argues that we will never know why cabinets chose to hang one man rather than another. «Anecdotal evidence was undoubtedly suggestive», she writes, «but it was impossible to prove that ethnicity, race or religion or any other single factor swayed the cabinet to opt for or against commutation ${ }^{24}$. Under mounting pressure to explain how mercy decisions were reached, the «Capital Case Procedure» manual was published in 1941. But Strange claims the manual disclosed very little. «It was one thing to assert that certain rules were followed; it was quite another to divulge how those rules were applied in practice ${ }^{25}$. Curiously, Strange finds a letter written by a Remission Officer asking for a salary raise more revealing of this mystery than the Capital Code Manual itself. The letter was written in 1923 by Michael Gallagher, who was Chief Officer from 1924 to 1953 . The listing of his duties included: «analysis of all evidence (...) irregularities at trial (...) consideration of legal points (...) alleged impaired mentality (...) collecting data bearing on character... such advice [is] tendered in keeping with the rules of exceptionality and natural equity; the determination of these rules and their application to each individual case are among the most important duties of office.» Strange then concludes from this job description:

that determining who ought to be executed and who ought to be spared was by no means a strict matter of rules and legal procedures. Like jury members' deliberations, remission officers' assessments of factors such as character and community feeling were more impressionistic than legalistic. Gallagher discreetly admitted that his subjective opinions, as well as his estimation of public opinion and the potential for political fall-out, played a pivotal role in determining his recommendations ${ }^{26}$.

It is puzzling to read that Strange finds the reasons for mercy a mystery. It is puzzling because she says that cabinets and Governor-Generals usually rubber-

\footnotetext{
22 Strange (1998b, p. 599).

23 Strange (1998a, p. 184).

24 Strange (1998b, p. 616).

25 Strange (1998a, p. 185).

26 Strange (1998a, p. 195).
} 
stamped the recommendation to mercy or execution that the Remissions Branch in the Justice Department offered them. Guy Favreau, Minister of Justice in 1941, did reveal that he read all the evidence in cases where execution was recommended, but only those parts of the evidence drawn to his attention by the Chief Officer of the Remissions Branch in cases where mercy was the recommendation. Strange concludes from this that the Remissions Branch «exerted enormous influence over the executive's final word ${ }^{27}$.This appears to be in line with practice in the English Home Office. There in the Criminal Department an archive of capital cases was kept together with tabulated memoranda of precedents for internal use. Chadwick has shown how this store of archival knowledge grew from 1860 so that by 1900 the bureaucrats were able to impose on the exercise of mercy «an increasing coherence and rationality ${ }^{28}$.

Yet Strange claims that the Canadian Justice Department kept no historical archive of precedents and that decisions were made on a random and ad hoc basis. Can this really be true, if the Canadian system was based on English practice? In England the view of the judge was the most important opinion in deciding on mercy. Between 1900 and 1950 only six men were executed against the recommendation of the judge ${ }^{29}$. It is revealing that the only reference Strange makes to the murder law or to the mandatory death penalty is in 1961 when two degrees of murder were introduced in Canada. "The immediate effect of the amendment was to spare the branch and Cabinet from having to deal with capital cases", she writes, «other than those involving convictions for 'planned and deliberate' murders $\leadsto$. These are the very words used to describe a recommendation for the introduction of a first-degree murder in the 1866 Royal Commission on Capital Punishment. And if they divided murder on this ground in 1961, it is fairly certain that this had been the practice in the mercy process for many years before. It is probable that the Canadians followed the English trend from the 1930s in restricting hanging to premeditated murders.

There is a larger question that a «no rules » approach to mercy begs. What was the purpose of mercy in capital punishment? Strange answers: «Mercy was to counterbalance terror, to insure fairness and equity (in the eyes of its supporters) or, as detractors charged, to reinforce the legitimacy of a fundamentally unjust political and economic order ${ }^{31}$. But there is little in this definition to distinguish mercy exercised in the eighteenth century from mercy in the twentieth century. Did mercy remain unchanged over three centuries? The King's mercy in the eighteenth century was undoubtedly arbitrary and served to reinforce in England, as Douglas Hay has so incomparably described, the legitimacy of the bloodiest capital code in Europe. Even while the power of the gentry to interfere in the exercise of mercy in the nineteenth century became circumscribed as the system of government became more democratic, the arbitrariness of decisions taken by the King in his Council remained. «In no other context was the power over life and death wielded», writes the historian, Vic Gatrell, «with such remote and capricious disdain » ${ }^{32}$. Lord Ellenborough,

\footnotetext{
27 Strange (1998a, p. 191).

28 Chadwick (1992, p. 166).

29 Royal Commission on Capital Punishment, 1949-1953, Report, Appendix VI.

30 Strange (1998a, p. 193).

31 Strange (1996, p. 599).

32 Gatrell (1994, p. 543).
} 
a member of the King's Council in 1828, was horrified at how decisions over who to reprieve and who to condemn were reached:

I am shocked by the inequality of punishment. At one time a man is hanged for a crime (....) because there are few to be hanged, and it is some time since an example has been made of capital punishment for this particular offence. At another time a man escapes for the same crime (...) because it is a heavy calendar, and there are many to be executed. The actual delinquency of the individual is comparatively little taken into consideration. Extraneous circumstances determine his fate ${ }^{33}$.

Is this what Strange means when she calls mercy arbitrary, ad hoc, or a lottery in the twentieth century? Surely the bureaucratic exercise of mercy, to use Chadwick's term, by the Home Office under the mandatory death penalty for murder from 1861 and the Justice Department in Canada from 1867 was different in degree and kind from the capricious mercy Hay and Gatrell describe? Surely mercy came to be used, as Justice Devlin complained, for the purpose of justice ${ }^{34}$ ? Or did the truth about mercy lie in Lord Samuel's remark that a degree of uncertainty in marginal cases was a good thing in deterring potential murderers ${ }^{35}$ ?

\section{4. - MURDER AND MERCY MYTHS}

Very few murderers were ever brought to trial let alone convicted. Consequently, for the purpose of deterrence the most had to be made out of those who were convicted. The aim of judicial punishment was purely exemplary. In 1845 a barrister told the Royal Commission on Criminal Law that prosecuting all crime was impossible and that the «only attainable object is example». In 1935 the Home Office admitted that the cases prosecuted were no more than a representative selection. Reference to these two pieces of evidence was made in a recent revealing article by Howard Taylor about criminal statistics and murder in England ${ }^{36}$. He argues that limited finance, and competition between central and local government over payment for prosecutions, restricted the number of criminals brought to trial. «Clearly, if the true amount of crime had been put down», he writes, «then the deterrent effect would have been corroded by the public realisation of the enormous extent of crime that went unpunished ${ }^{37}$. It was cheaper and more effective to maintain «the public illusion' that criminals were caught and crime did not pay».

Taylor argues that the low murder rate in England was a myth. «From the midnineteenth century to the mid-twentieth », he writes, « it was popularly put about that murder was not a problem because the English people were so civilised ${ }^{38}$. Taylor suggests that the low murder rate was the result of prosecution policy and not the real incidence of murder. Between 1880 (when the Office of the Director of Public

33

Quoted in Gatrell (1994, p. 548).

Gowers (1956, p. 32) quoting from an article by Lord Devlin in the Criminal Law Review, September 1954.

Royal Commission on Capital Punishment, 1949-1953, Report, p. 16.

Taylor (1998, p. 573).

Taylor (1998, p. 581).

Taylor (1998, p. 584). 
Prosecutions was created) and 1965 (when capital punishment was abolished) the average number of murders recorded each year was 150 . Throughout this period the number of murders prosecuted fluctuated between 120 and 179. Taylor concludes that prosecution for murder was «the most strictly rationed of all crimes» and he argues that it was easy for the Director of Public Prosecutions to enforce quotas on murder. When the budget for murder was used up, the remaining murders were passed back to the police to prosecute at lesser charges. «Most murders did not get as far as a report to the Director of Public Prosecutions. Because the discovery of a suspicious death and its subsequent investigation and prosecution could make a large dent in a police authority budget, it was an open secret that most murders went uninvestigated $\aleph^{39}$. He goes further and suggests that sentences were also allotted according to quota. And the murder conviction rate in England and Wales between 1860 and 1950 was a suspiciously consistent 40 per cent. All in all, Taylor concludes that punishment had less to do with justice than with «bureaucracy and social policy ${ }^{40}$.

Taylor does not talk about execution by quota, but he might have made a case for that as well. The Royal Commission on Capital Punishment (1949-1953) was bothered about what appeared to be shifts in the reprieve rates from decade to decade. The 1930s stand out as a decade of leniency. But if the first half of the twentieth-century is divided into pre- and post-1925 periods the figures are $35 \%$ and $39 \%$ reprieved respectively. The Commission feared this four per cent difference might have indicated a change in mercy practice at the Home Office, especially considering the growing number of murderers reprieved on account of mental abnormality (despite a steady rise in cases of insanity on arraignment and guilty but insane verdicts). They did not suspect that premeditation had become the key to hanging murderers and concluded simply that there was an "increased tendency to leniency ${ }^{41}$. Moreover, the Commission was told that sharp statistical variations were inevitable when dealing with a crime as heterogeneous as murder. «The figures for men still show considerable fluctuation from one decade to another», it noted:

but they do not support any firm inference unless it were assumed that the proportion of heinous to less heinous murders remains approximately constant. That is not so. Murders are heterogeneous, and even in a period of 10 years the numbers are so small that fortuitous circumstances (such as the variations in the number of murders of wives, sweethearts and mistresses, or the recent increase in the number of murders in connection with robbery and sexual assault, to which the Home Office drew attention) have an exagerrated effect on the percentages ${ }^{42}$.

The Commission also noted that Scottish mercy had always been more lenient than English mercy and that there had been no executions in Scotland between 1928 and 1945. Part of the reason for this was that «Scottish juries can and do return a verdict of culpable homicide on the ground of diminished responsibility in cases of lesser mental abnormality, where in England a verdict of murder would be inevitable ${ }^{43}$.

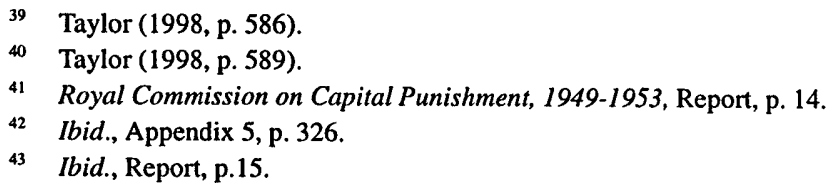


The reprieve rate in Canada lurched from decade to decade. In the 1870 s over 70 per cent of murderers were reprieved; in the 1910s about 50 per cent; and in the 1930 s only 25 per cent (in sharp contrast to England) ${ }^{44}$. The conclusion Strange draws from these swings is that the award of mercy was arbitrary. "These statistics were not printed on a yearly basis, but unprecedented execution rates and erratic swings in severity and mercy raised troubling questions for concerned observers », she writes. «What could account for such dramatic shifts in execution and commutation patterns if capital case review procedures were systematic and impartial? ${ }^{45}$.

The answer is most obviously politics. It should comes as no surprise that execution rates were unstable in colonies where the process of colonialism involved the conquest and incorporation of indigenous peoples and the suppression of working class struggles. Hanging rebels and strikers made as big an impact on the statistics as hanging ten Chinese for a robbery murder on the Rand in 1910. Hanging rows of men for ritual murders had a similar effect in the early years of the twentieth century. This explains the anomaly of liberal Lord Gladstone's hanging record in South Africa. As Home Secretary in England (1905-1910), he was a weak believer in capital punishment. But as Governor-General in South Africa he allowed more men to hang in 1910 and 1911 than any of his pre-1948 successors.

Gladstone relied on exemplary hangings to control witch murder in specific areas. More than a half of those hanged in 1911 were witch murderers. «When they come before me whether as Governor General or High Commissioner », he wrote, «I pay attention to what the likeliest authority, who knows the district where the crime is committed, says with regard to deterrence. And I have several times referred cases back for such opinion». Then if the incidence of witch murder was growing, he allowed «the law to take its course» in order to make an example. $\mathrm{He}$ summed up the policy he followed in these cases in the following way: «Where it is clear that murder is due to smelling out, to prevalent native superstitions, to ignorance and a low order of intelligence, the death penalty should not be inflicted unless competent local authorities think it essential for public reasons ${ }^{46}$. Gladstone's essentially arbitrary policy of capital punishment for witch murder was replaced by a more individualistic approach to mercy by his successor, Lord Buxton. The death sentence was carried into effect when the doctor himself was the murderer and commuted when the murderers had killed the wizard (or witch) indicated by the doctor ${ }^{47}$.

More importantly the aim of hanging was, as Lord Gladstone indicated, the exemplary one of deterrence. At the turn of the century British Governor-Generals had little doubt that the judicious use of the mercy prerogative did much to legitimate their right to rule colonial peoples. For example, in 1910 Louis Botha, the Prime Minister of South Africa, warned Gladstone that if he commuted a rape death sentence there «wd be strong feeling in Rhodesia, \& the whites would believe the woman". Botha also told him that there «had been dangerous feeling some time

\footnotetext{
44 Strange (1996, p. 613, fn 54 quoting from Favreau, 1965).

45 Strange (1998a, p. 190).

46 National Archives of South Africa (Pretoria), GG 51/5599, Sentences: General Questions. HE Lord Buxton's notes on the question of Witchcraft Murder cases, 11 August 1920, enclosing Gladstone's Minute, 26 November 1912, p. 6.

47 Ibid., Law Adviser's Analysis, 13 November 1917.
} 
ago, but an execution had up to now stopped outrages ${ }^{48}$. But Gladstone kept his own counsel and commuted. Governor-Generals continued to apply capital punishment in an exemplary fashion where they saw murder or crime growing in a particular region. "Judging by the number of cases from Natal which are now being submitted to YRH», wrote the secretary to Prince Arthur, Governor-General, in 1921, « it is evident that the crime of murder is on the increase in that Province, and it seems clearly desirable that the law should be allowed to take its course in this case $»^{49}$. But the exemplary function of hanging changed in political and moral time. By the 1930s the role of the imperial British Governor-General was over in the South African mercy process; in 1937 the first South African, Patrick Duncan, was appointed Governor-General; and thereafter Governor-Generals never vetoed a cabinet recommendation on a death-penalty offence.

\section{5. - SOUTH AFRICA: HYBRID MERCY RULES}

In South Africa the reprieve rate in the first half of the twentieth century was close to 80 per cent, much higher than both England and Canada. But in South Africa few murderers were found insane on arraignment or "guilty but insane» in trials and it is difficult as a result to make a clear comparison. What can be said is that over the first half of the twentieth century the pattern of reprieves followed the English with mercy becoming more lenient from the 1930s. The mercy reports from this time reveal a much closer concern with premeditation and the motives for murder. In 1935 the mandatory death penalty for murder was abolished in an attempt to shift the growing burden of processing hanging cases from the Executive to the courts. But prior to 1935 the South African mercy process was modelled on practice in the Home Office. In the National Archives of South Africa capital case files containing material similar to those in the Canadian archives have been kept for posterity, but unlike the Canadian Archives any quantifiable information has to be prised out by hand. For the period between 1910 and 1947 there are 1536 capital case files, of which I have sampled $384^{50}$.

What do these files reveal about the mystery of mercy? Comparison of gain and passion murders or of racial with intra-racial murders tell us very little about how mercy was awarded. The maintenance of social and racial hierarchy was always a predominant factor in these cases. Let us consider three similar intra-racial domestic murders for an insight into the secret negotiations over life and death. The first involved the murder of a sexual rival. In 1920 Hubert Fisher, a forty-one year-old divorced mechanic, was in love with twenty-five-year-old Mary Davidson. He boarded with her family in Kimberley, a town built around diamond mining. When she transferred her affections to a younger man, recently returned from service during the war, it was too much for the older man to bear. He owned an automobile and considered himself a good deal better than that «damned common Tommy Knight». He shot his rival dead on the night Mary Davidson announced her enga-

48 British Library, Viscount Gladstone Papers, Add.Mss. 46097, Gladstone hand-written note on Government House, Cape Town paper [1910], p. 146.

49 Ibid., Hazelrigg to H.R.H. Prince Arthur Frederick (Governor-General), 1 January 1921.

so See Turrell (2000). 
gement to the younger man. «It would seem only too clear from all the evidence», concluded Judge de Waal in his confidential report, «that the prisoner after he had located Knight and Miss Davidson on the seat deliberately returned to his room to fetch his loaded pistol and that after he had made sure on his return that the couple on the seat were the two he wanted deliberately and intentionally fired at and killed Knight, and it is difficult to see how the Jury, who were unanimous in their verdict, could have arrived at any other conclusion $" 51$.

The proof of deliberation was only reached after an accumulation of evidence revealed a motive of revenge. The most convincing piece of evidence lay in a diary Fisher kept on the counsel of the Efficiency Association «which advised pupils to analyse their perplexities ». Instead of providing a record of despair, Judge de Waal believed he kept the diary because he was brooding on revenge. "As it stands the Diary, if a curious self revelation, furnishes the strongest evidence of malice ${ }^{52}$. He even reached the conclusion that Fisher's interest in Davidson was «entirely sensual and material», a conclusion the defence unwittingly reinforced.

Advocate Krause K.C., the best trial lawyer in the land, made a defence out of jealousy and a broken promise of marriage to suggest an unhinged mind. He subjected Davidson to a remorseless cross-examination to show that she had allowed Fisher « to take undue liberties with her modesty », that is, have regular sexual intercourse with her over the previous four years. But medical evidence revealed that Davidson was a virgin and so his defence back-fired. Instead, the jury believed he had made an underhand attack on her honour, and he was unable to convince them that he had only put her veracity to a stern test. Thus, Fisher's fate was sealed. «The mere fact that he had rightly or wrongly come to regard Miss Davidson as his future wife », wrote the Minister of Justice, «cannot be entertained as an extenuation for the deliberate murder of which he was rightly found guilty (...) $»^{53}$.

This conclusion of deliberate murder conceals more than it reveals. First, in the post-war decade judges were harsh on white working men who plead jealousy as excuse for murder. The power of the white working class was particularly threatening to social hierarchy in the light of the apparent success of communism after the war. Second, Knight was the son of a large employer of white labour in Kimberley and had a «pull» on the jury. And third, Fisher won no sympathy from the Judge, whose opinion carried the most weight in the mercy process. "No Britisher», he said in the last letter he wrote, "should be tried by a Dutch judge».

The second case has much in common with the first. But here a murder was judged to be both deliberate and impulsive. In 1926 the twenty-three-year-old Herman Charles Bosman, who was to become South Africa's most famous comic writer $^{54}$, was sentenced to death for the murder of his step-brother. The Judge, jury, Prosecutor, Attorney-General, Law Adviser and Minister of Justice all believed he had deliberately killed his step-brother. Yet his defence was that he shot his stepbrother by accident. "In that tragic minute, the happenings of which are still not

51 National Archives of South Africa (Pretoria), JUS, unnumbered 2/2/10, Rex versus H.W. Fisher: murder, Judge's report (D. de Waal), 4 September 1920, pp. 10-11.

$52 \quad$ Ibid., p. 7.

53 Ibid., Minister of Justice's report (N.J. de Wet), 18 September 1920, p. 9.

54 He was the author of Cold Stone Jug, Mafeking Road, Unto Dust, Jurie Steyn's Post Office, A Cask of Jerepigo, Jacaranda in the Night, Willemsdorp and A Bekkersdal Marathon. 
clear to me», Bosman said, «I was impelled by some wild and chaotic impulse in which there was no suggestion of malice or premeditation». A more conniving and disingenuous statement was difficult to imagine. He had been well coached by an excellent advocate. But he did not fool Judge van Pittius. In his eyes Bosman behaved like a guilty man after the killing rather than someone who had been the cause of a fatal accident. The unavoidable fact was that Bosman loaded the rifle before shooting his step-brother. So the Judge sentenced him to death in court as the law required under a mandatory death penalty for murder. But the road to a reprieve had already begun with the favourable impression the Judge formed of Bosman during the trial. He was stunned by Bosman's imagination and sensitivity. In the privacy of his mercy report he prayed not only for a reprieve, but for a short sentence.

The Judge left it to others to explain to the Governor-General what he meant by his mercy recommendation. The acting Attorney-General wrote: "What he clearly excludes in this case is anything in the nature of a calm contemplation of the result of the act, which he was about to perform ${ }^{55}$. This was, in fact, the precise meaning of the word deliberate. The Prosecutor added: «The Court found that the shooting was deliberate but I feel sure that the presiding Judge will agree that it was done on the impulse of the moment $"$. The Minister of Justice put the case into a broader perspective. Bosman considered his mother had remarried into a «common» family soon after his father's death and regarded himself as a stranger in her house in Johannesburg. "There is no doubt that his unhappy family relationship preyed upon his mind", he said, repeating a hint from the Judge. Thus the Minister's mercy recommendation was formulated as follows:

I am satisfied that prior to the altercation between Pierre Bosman and David Russell there was no contemplation of murder or bodily harm in the mind of the accused, but at the moment when he heard the altercation he took up the rifle with deadly intent and deliberately used it in circumstances in which a simple intervention in the struggle going on between his brother and Russell would have afforded adequate protection to the former. At the same time, having regard to the state of mind of prisoner and to the sudden impulse which influenced him, I think the justice of the case would be met by a commutation of the sentence to imprisonment for a term less than the usual life-long period ${ }^{57}$.

He recommended ten years. Bosman received this sentence, but served under four before he was released on probation.

What made Bosman's brooding over his unhappy family situation more deserving of sympathy than Fisher's obvious distress at losing the love of his life ? As with Fisher's murder there were a number of other issues that influenced the outcome of the case. First, the motive of revenge was by no means as clear in a sibling as in a sexual-rival murder, although a short story written by Bosman about the murder of a brother was put into the record as evidence of premeditation. Second, Bosman was «a well educated but imaginative and sensitive youth» at the beginning of a career as a teacher. Third, he was a leader of the White League, an

ss National Archives (Pretoria), GG 51/8063, Sentences: Capital: HC Bosman, Acting AttorneyGeneral's report (George Brebner), 2 December 1926, p. 2.

56 Ibid., Crown Prosecutor's report (C.C. Jarvis), 18 November 1926, p. 2.

57 Ibid., Minister of Justice's report (Tielman Roos), 24 December 1926, p. 8. 
anti-Communist organisation whose goal was the maintenance of white supremacy in South Africa. He had taken part in breaking up Communist meetings, been threatened with violence for his pains and given police protection. Fourth, Bosman, who was of Dutch origin, was tried by a sympathetic Dutch Judge ${ }^{58}$.

The third murder illustrates the most distasteful form of South African mercy. Here mercy was granted as a political favour. On 20 August 1920 Chief Matlala killed Elias Lemola, his subject and Pietersburg District leader of the Transvaal African Congress. The case for the defence was that Lemola had been caught naked in the hut of one of Matlala's ten wives. Matlala « killed him in a fit of rage induced by this violation of the chastity of his wife and of his own honour ». In his version of events the killing took place inside the hut at 11 p.m and then the body was taken outside into the night light to see who the victim was. The case for the Crown was that much earlier, at sunset, Lemola was found in the skerm outside Maria's hut about to take an evening meal. Matlala and his brother killed him outside the hut with a kaffir hoe (like a pick axe), forcibly undressed him to make him look like an adulterer and carried his body inside the hut. The motive for the crime was that the Transvaal African Congress was undermining Matlala's authority.

What was crucial to the outcome of this case was the popularity of Matlala amongst the white farmers of the district. His popularity had deep roots. Chief Matlala's ancestors had a long history of loyalty to the Boer Republic in the Transvaal and after the Anglo-Boer War Matlala continued to win words of praise from Native Affairs officials and white farmers. What this meant was that Matlala was tried by a jury of white farmers who were his peers rather than his enemies. Moreover, for his defence he had been able to engage the famous advocate Krause K.C.

Yet even with the odds stacked in Matlala's favour, the jury found him guilty of a deliberate murder. There were a number of reasons for the jury's verdict, but the blood evidence was the most convincing. In fact, the whole case turned, in true Rumpole style, on bloodstains. They revealed whether Lemola was killed inside or outside the hut. If he was killed inside the hut, then Matlala was guilty of a justifiable culpable homicide on the grounds of provocation. If he was killed outside the hut, then Matlala was guilty of a « wicked murder » committed out of political animosity and he deserved to hang. The biggest blood stain was outside the hut. «The medical evidence was conclusive», wrote the Prosecutor, Eugene Marais, «on the point that the greatest and strongest rush of blood would take place immediately after the arteries in the neck had been severed and while the heart was still acting ${ }^{59}$. There were spots of blood all over the skerm that suggested a great struggle had taken place. Lemola suffered ten wounds. What the blood stains indicated was that he had been

58 The legal records of the Bosman murder conceal, perhaps less successfully than other murder records, more than they reveal. It is worth while noting that Valerie Rosenberg writes in her biography of Bosman, Sunflower to the Sun (1976) that he was the product of sibling incest, that he knew his father was his uncle, Charles Malan, who was an attorney, the Secretary of the South African Party in the Transvaal and a close friend of General Jan Smuts. Moreover, Bosman's youngest uncle, Fred Malan, was an advocate and later became a Judge of the Appeal Court. This familial connection to law and politics does not imply a direct perversion of the course of justice, but it does explain the sympathy of the judge and the rapid reduction of Bosman's sentence from death to ten years and then to five years before his release on probation.

59 National Archives of South Africa (Pretoria), GG 51/5754, Sentences Capital: Sekgoari Motlishi Matlala, Masheane Matlala, Prosecutor's report (Eugene Marais), 28 October 1920, p. 4. 
killed outside, wrapped in a kaross and then carried into the hut twelve hours later. Post-mortem haemorrhage accounted for the blood stain on the hut floor and the shaking of the kaross for the blood spots high on the wall.

Despite the verdict of the jury, Judge Curlewis thought there was some doubt in the case. As always the judge's opinion weighed most heavily in the scales of mercy. He thought the eight-to-one jury verdict indicated some of the problems in reaching a clear decision. He pointed out that Maria was an interested witness who was refuting a charge of infidelity. Her sister and her brother supported her version of events. All had reason to be hostile to Matlala. He had burned their huts and turned them out of the hoofstad two years before on account of her family's refusal to allow her sister to marry Matlala. Consequently, he believed something of the defence and recommended commutation ${ }^{60}$.

The judge was not alone in arguing for a reprieve. A monster petition from whites in the Pietersburg District prayed for mercy. In addition, the Department of Native Affairs wrote «that Matlala has always been loyal and ready to assist the Government in regulating the affairs of his tribe». The Chief Native Commissioner in Natal, who had been the former Magistrate and Native Commissioner of Pietersburg, wrote that the case deserved the "most sympathetic consideration». Even though the Minister of Justice noted that he was happy to accept the verdict of the jury, this phalanx of white opinion was hard to resist. He followed their lead and recommended life for both men $^{61}$.

That was not the end of the matter. It was up to the Governor-General, Prince Arthur of Connaught, the third son of Queen Victoria, to make the final decision. On the chronological schedule of his copy of the mercy record the following was written in pencil by his secretary, G. Hazelrigg: «Chief and his brother murder leader of the 'Kongres' - Some element of doubt about the real circs of the murder - Agree to commute to life sentence in both cases ». There was subsequently a seachange in opinion at the Executive Council meeting. Astonishment at what transpired was shown in the cryptic exchange of minutes on the cover of the mercy file. «The Minister recommended that the death sentence in each case be commuted to imprisonment for life», minuted a clerk in the Governor-General's office. «Mr Hazlerigg concurred but the sentence in each case, as approved in $\mathrm{Ex} \mathrm{Co}$, has been altered to two years ». Below was written another minute noting that the Clerk of the Executive Council was certain this was «in accordance with decision of H.R.H.». Mr Hazlerigg then asked Prince Arthur: «I understand that two years is correct?» And Prince Arthur simply initialled the minute without comment.

\section{6. - CONCLUSION}

A consideration of these three cases suggests that the South African exercise of mercy took elements from the three interpretations of Radzinowicz and Hood, Chadwick, and Strange. The combination of both legal and moral and arbitrary positions is confirmed by the way mercy was exercised in South Africa. There is little doubt that a deliberate and planned murder was the basic standard against which the

60 Ibid., Judge's report (J.S. Curlewis), 29 November 1920.

61 Ibid., Minister of Justice's report (H. Mentz), December 1920, p. 6. 
death penalty was measured. Radzinowicz and Hood were quite right on this point. Yet it is equally clear that some deliberate murders, like the one committed by Bosman, were excused by some mitigating factor, such as who the murderer and his victim were and the position they occupied in the racial or social hierarchy, while many others were hanged for deliberate murders alone. Here Chadwick was correct. There is also little doubt that many men were executed for impulsive or unpremeditated murders, while many more were reprieved. Here there was nothing to choose between exemplary justice from the point of view of criminal deterrence and the Strange view of arbitrariness from the point of view of the murderer hanged.

The turning point was the 1930s and the impact of the Great Depression. In England and in South Africa, but not in Canada, mercy became more lenient thereafter than ever before. There was a much closer attention to the mind of the murderer and premeditation became the litmus test of a bad murder. Yet the law itself remained conservative. In 1935 a Bill that differentiated between two degrees of murder on the basis of premeditation was rejected by the South African Parliament and replaced instead by the introduction of «extenuating circumstances » in the murder law. This was solidly in line with the English law that had been indigenised in South Africa over the previous hundred years. The law on murder was designed to stamp out all homicidal violence, whether it was premeditated or impulsive.

Yet after 1935 there was a de facto movement towards punishing by the death penalty only murders containing both the elements of deliberation and planning. After the War the use of the word deliberate disappeared from the mercy reports and premeditation came to be the code word for execution. Between 1960 and 1990 the General Bar Council judged that the death sentence was likely to be imposed in cases where: «(a) the murder was committed in the course of some other crime, particularly robbery and rape; (b) the murder was carefully planned and premeditated or fell in the category of a 'contract' killing; (c) the circumstances of the commission of the crime were attended by peculiar and marked brutality ${ }^{62}$.

\author{
Rob Turrell \\ UCT \\ Faculty of Humanities \\ Beattie Building \\ Private Bag \\ South Africa \\ Rondebosch 7701 \\ rturrell@beattie.uct.ac.za
}

\title{
References
}

Avio, K., The quality of mercy: exercise of the royal prerogative in Canada, Canadian Public Policy 1987, pp. 366-379.

Avio, K., Capital punishment: statistical evidence and constitutional issues, Canadian Journal of Criminology, 1988, 30, 3, pp. 331-349.

62 Composite Truth and Reconciliation Commission submission by the General Council of the Bar of South Africa (GCB), 18 October 1997, Vol II, «Law in South African Society 1960-1994', paragraphs 102. 
British Parliamentary Papers, Cmd. 8932, Royal Commission on Capital Punishment, 1949. 53.

Chadwick, R., Bureaucratic Mercy. The Home Office and the Treatment of Capital Cases in Victorian Britain, Rice University Ph.D thesis (1989), New York, Garland Publishing, 1992.

Chandler, D., Capital Punishment in Canada, Toronto, Mc Clelfand \& Stewart, 1976.

Evans, R., Rituals of Retribution. Capital Punishment in Germany, 1860-1987, Oxford, Oxford University Press, 1996.

Favreau, G., Capital Punishment: Material Relating to its Purpose and Value, Ottawa, 1965.

Gatrell, V.A., The Hanging Tree. Execution and the English People 1787-1868, Oxford, Oxford University Press, 1994.

Gowers, E., A Life for a Life? The Problem of Capital Punishment, London, Chatto and Windus, 1956.

Hay, D., Property, authority and the criminal law in Hay, D., Linebaugh, P., Rule, J.G., Thompson, E.P., (Eds.), Albion's Fatal Tree. Crime and Society in Eighteenth-Century England, Harmondsworth, Penguin, 1977, pp. 17-63.

Jayewardene, C.H.S., The Penalty of Death: The Canadian Experiment, Lexington, Mass., 1977.

Radzinowicz, L., Hood, R., A History of English Criminal Law and its Administration from 1750. Volume 5. The Emergence of Penal Policy, London, Stevens and Sons, 1986.

Rosenberg, V., Sunflower to the Sun, Cape Town, Human \& Rousseau, 1976.

Strange, C., (Ed.), Qualities of Mercy: Justice, Punishment and Discretion, Vancouver, University of British Columbia Press, 1996.

Strange, C., Comment: «Capital cases procedure manual», The Criminal Law Quarterly, 1998a, 41, 2, pp. 184-197.

Strange, C., Stories of their lives: The historian and the capital case file, in Iacovetta, F. and Mitchison, W., (Eds.), On the Case: Explorations in Social History, Toronto, University of Toronto Press, $1998 \mathrm{~b}$, pp. 25-48.

Strange, C., The lottery of death: capital punishment, 1867-1976, Manitoba Law Journal, 1996, 23, 3, pp. 594-619.

Taylor, H., Rationing crime: the political economy of criminal statistics since the $1850 \mathrm{~s}$, The Economic History Review, 1998, 3, pp. 569-590.

Troup, C.E., The Home Office, London, 1925.

Turrell, R., Capital and Labour on the Kimberley Diamond Fields, 1871-1890, Cambridge, Cambridge University Press, 1987.

Turrell, R., White Mercy. A History of Murder and Rape in South Africa, Cape Town, University of Cape Town Press, 2000. 